\title{
PENENTUAN BIAYA PELAYANAN PENGGERGAJIAN KAYU DENGAN METODE ACTIVITY BASED COSTING
}

\author{
Nugroho, Mochammad Chaeron, dan Gunawan Madyono Putro \\ Jurusan Teknik Industri, Fakultas Teknik Industri \\ Universitas Pembangunan Nasional "Veteran" Yogyakarta \\ Jl. Babarsari 2 Tambakbayan, Yogyakarta, 55281 \\ Telp. (0274) 485363 Fax.: (0274) 486256
}

\begin{abstract}
ABSTRAK
UD. Karya Nugraha merupakan perusahaan di bidang jasa penggergajian kayu. Produk yang dihasilkan adalah kayu gergajian (KG) kecil, kayu gergajian besar dan kayu gergajian campur. Harga pokok pelayanan dipatok sama untuk semua produk sebesar $\mathrm{Rp}$. 195.000,00/ $\mathrm{m}^{3}$ padahal aktifitas pekerjaan pada masing-masing produk berbeda.

Activity Based Costing merupakan metode penentuan harga pokok yang menelusuri biaya keseluruh aktivitas, kemudian dibebankan pada produk. Tahapan penelitian ini dibagi menjadi tiga kelompok, kelompok pertama meliputi; mengidentifikasi aktivitas, menentukan biaya terkait, mengelompokan aktivitas yang seragam, dan menggabungkan biaya dari aktivitas yang dikelompokan. Tahapan kedua meliputi; perhitungan biaya pembebanan pada tiap aktivitas. Dan tahap ketiga membandingkan biaya hasil perhitungan dengan perhitungan perusahaan untuk mengetahui overcost dan undercost produk.

Hasil perhitungan biaya dengan metode activity based costing untuk produk KG kecil Rp.

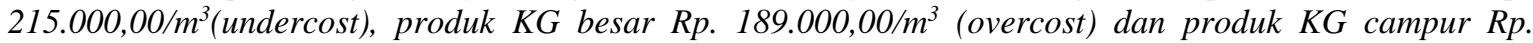
$175.000,00 / \mathrm{m}^{3}$ (overcost).
\end{abstract}

Kata kunci: Harga pokok produksi, activity based costing

\section{PENDAHULUAN}

UD. Karya Nugraha (KN) merupakan perusahaan jasa penggergajian kayu yang beralamat di jalan Rembang-Blora Km.6 desa Pedak kecamatan Sulang Kabupaten Rembang. U.D. KN merupakan industri primer yang mengolah bahan baku berupa kayu bulat menjadi barang setengah jadi atau barang jadi. Hasil dari pengolahan kayu menjadi kayu gergajian dapat dijadikan bahan baku oleh industri kayu lanjutan seperti moulding, flooring, dan lainnya, selain itu hasil kayu gergajian juga bisa langsung dikonsumsi misalnya digunakan untuk konstruksi bahan bangunan. Kapasitas produksi yang dimiliki oleh perusahaan sebesar $2000 \mathrm{~m}^{3}$ per tahun dengan jumlah tenaga kerja keseluruhan sebanyak 21 orang. Saat ini harga pokok pelayanan dipatok sama untuk semua produk sebesar Rp. 195.000,00/ $\mathrm{m}^{3}$.

Penetapan harga produk merupakan salah satu keputusan yang sulit bagi manajemen perusahaan. Dasar penetapan harga yang dipakai setiap perusahaan relatif sama, yaitu berdasarkan pada biaya, persaingan, permintaan dan laba.
Pembebanan biaya dengan sistem tradisional sebenarnya tidak menunjukkan biaya yang sesungguhnya dikonsumsi oleh setiap jenis produk. Pengalokasian dengan metode ini akan menyebabkan distorsi, karena produk tidak mengkonsumsi biaya secara proporsional terhadap volume produksi. Produksi dengan volume tinggi akan mensubsidi produk dengan volume rendah, sehingga terjadi subsidi silang.

Activity-Based Costing System merupakan metode yang dapat membatasi distorsi dan subsidi silang yang disebabkan oleh pengalokasian sistem akuntansi biaya yang tidak tepat. Fokus utama Activity Based Costing System adalah aktivitas, karena pada dasarnya pengelolaan manajemen merupakan perencanaan dan pengendalian aktivitas untuk mencapai tujuan tertentu. Dalam perusahaan semua aktivitas ditujukan untuk menghasilkan produk dengan biaya memadai. Dengan demikian, fokus utama manajemen adalah pada pengelolaan aktivitas, yaitu merencanakan dan mengendalikan seluruh aktivitas perusahaan dalam menghasilkan produk dengan tingkat biaya semestinya. Berdasarkan keadaan di 
atas, penelitian ini dimaksudkan untuk menentukan harga pokok produk pelayanan di UD. KN menggunakan metode Activity Based Costing (ABC).

\section{LANDASAN TEORI}

Menurut Garrison dan Norren (2000) "activity based costing adalah sistem perhitungan harga pokok produksi yang dirancang untuk menyediakan informasi biaya bagi manajer untuk pembuatan keputusan strategi dan keputusan lain yang mempengaruhi kapasitas dan biaya tetap." Dasar pemikiran pendekatan perhitungan harga pokok produksi berdasarkan aktivitas ini adalah bahwa produk atau jasa perusahaan merupakan hasil dari aktivitas dan aktivitas tersebut menggunakan sumber daya yang menyebabkan timbulnya biaya. Biaya dari sumber daya dibebankan ke aktivitas berdasarkan aktivitas yang menggunakan atau mengkonsumsi sumber daya (penggerak konsumsi sumber daya) dan biaya dari aktivitas dibebankan ke objek biaya berdasarkan aktivitas yang dilakukan untuk objek biaya berdasarkan aktivitas yang dilakukan untuk objek biaya (penggerak konsumsi akitivitas). Activity based costing mengakui hubungan sebab akibat atau hubungan langsung antara biaya sumber daya, penggerak biaya, aktivitas, dan objek biaya dalam membebankan biaya pada aktivitas dan kemudian pada objek biaya.

Activity based costing (ABC) merupakan suatu sistem yang menyediakan data biaya produk dan informasi biaya lainnya untuk manajemen dalam pembuatan keputusan. Dasar pemikirannya dilandasi oleh keyakinan dasar bahwa biaya ada penyebabnya dan penyebab biaya dapat dikelola. Penyebab biaya adalah aktivitas, dan melalui penyediaan informasi lengkap tentang aktivitas kepada personel maka personel akan dapat melakukan pengelolaan terhadap aktivitas (Mulyadi, 2005). Activity Based Costing menyatakan bahwa aktivitaslah yang menyebabkan munculnya biaya dan produk mengkonsumsi aktivitas. Karenanya mengidentifikasi aktivitas merupakan kegiatan yang penting dalam penerapan sistem ABC. Sistem ABC membagi aktivitas menjadi dua kelompok yaitu: Product driver activity dan Customer driven activity.

Product driver activity merupakan aktivitas yang berhubungan dengan kegiatan meran-cang dan memproduksi suatu produk, dibedakan menjadi empat, yaitu:

1. Unit-levels activities

Aktivitas berlevel unit (unit-level activities) adalah aktivitas yang dikerjakan setiap kali satu unit produk diproduksi.

2. Batch-related level activities

Aktivitas-aktivitas berlevel batch (batchrelated level activities) adalah aktivitas yang dikerjakan setiap kali suatu batch produk diproduksi.

3. Product-sustaining level activites

Aktivitas-aktivitas berlevel produk (product-level activities) disebut juga sebagai aktivitas penopang produk (product-sustaining activities) yaitu aktivitas yang dikerjakan untuk mendukung berbagai produk yang diproduksi oleh perusahaan.

4. Facility-sustaining level activities

Aktivitas berlevel fasilitas (Facilitysustaining level activities) adalah meliputi aktivitas untuk menopang proses manufaktur secara umum yang diperlukan untuk menyediakan fasilitas atau kapasitas pabrik untuk memproduksi produk, namun banyak sedikitnya aktivitas ini tidak berhubungan dengan volume atau bauran produk yang diproduksi.

Customer driven activity adalah aktivitas yang berhubungan dengan kegiatan penawaran, pelayanan serta dukungan terhadap pelanggan atau pasar perusahaan, meliputi:

1. Order level

Aktivitas ini berhubungan dengan pesanan pelanggan. Biaya dibebankan secara langsung pada penjualan dan pesanan yang dilakukan pelanggan secara individu. Contohnya biaya pengiriman pesanan.

2. Customer level

Aktivitas ini tidak berhubungan dengan pesanan, tetapi biaya yang terjadi dibebankan kepada pelanggan.

3. Market level 
Aktivitas ini dibutuhkan $\begin{array}{r}\text { untuk } \\ \text { mempertahankan }\end{array}$ pasar tertentu. Contohnya aktivitas promosi dan periklanan.

4. Channel level

Aktivitas ini dibutuhkan dalam saluran distribusi dan tidak ditentukan berdasarkan pesanan pelanggan.

5. Enterprise level

Aktivitas ini merupakan kegiatan yang dilakukan agar perusahaan mampu bertahan dalam persaingan bisnisnya. Biaya yang ditimbulkan tidak dapat dibebankan pada level yang lebih rendah. Contohnya adalah biaya lisensi, pajak, dan gaji direktur.

Desain ABC difokuskan pada kegiatan, yaitu apa yang dilakukan oleh tenaga kerja dan peralatan untuk memenuhi kebutuhan pelanggan. Dengan memusatkan perhatian pada kegiatan dan bukannya departemen atau fungsi, maka sistem $\mathrm{ABC}$ akan dapat menjadi media untuk memahami, memanajemeni, dan memperbaiki suatu usaha. Struktur sistem ABC digambarkan pada Gambar 1.

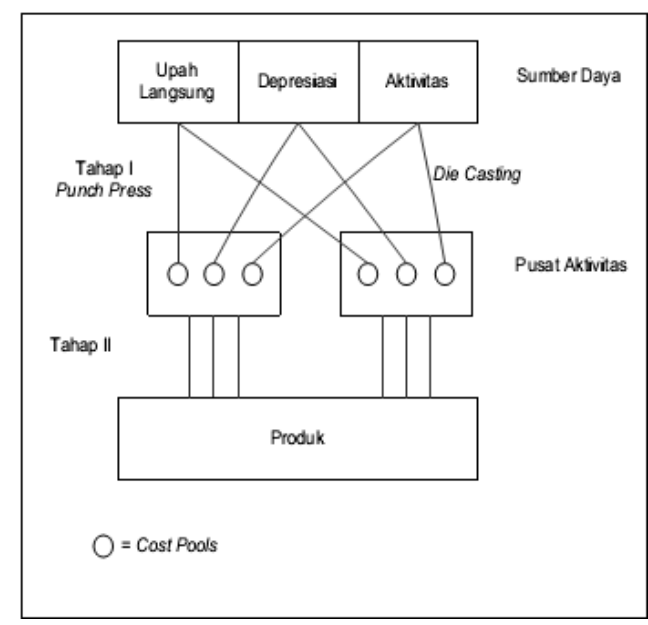

Gambar 1. Struktur ABC

(Sumber: Tunggal, 1992)

Prosedur tahap I: Pembebanan biaya ke aktivitas. Pada tahap pertama ini dilakukan pembebanan biaya pemakaian sumber daya kepada aktivitas-aktivitas. Dalam kalkulasi biaya berdasarkan sistem ABC tahap pertama, pembebanan dilakukan pada biaya overhead. Struktur pembebanan biaya ke aktivitas ditunjukkan pada Gambar 2.

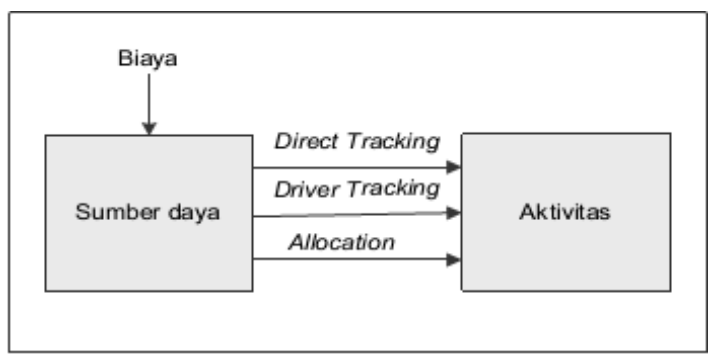

Gambar 2. Prosedur tahap I

(Sumber: Tunggal, 1992)

Ada dua hal penting yang harus diperhatikan untuk dapat menerapkan tahap pertama, yaitu:

1. Identifikasi pemicu biaya (cost driver)

Pemicu biaya adalah faktor yang dapat menerangkan konsumsi biaya-biaya overhead. Faktor ini menunjukkan suatu penyebab utama tingkat aktifitas yang akan menyebabkan biaya dalam aktifitas. Beberapa pemicu biaya yang digunakan adalah sebagai berikut:

a. Kelompok tenaga kerja (Labour group)

Kelompok ini dipakai dalam aktivitas yang elemen biaya utamanya adalah tenaga kerja atau pada aktivitas yang biaya aktivitasnya berubah secara paralel dengan perubahan tenaga kerja baik tenaga kerja langsung ataupun tenaga kerja tidak langsung. Total biaya tenaga kerja tidak langsung (indirect labour cost) dapat diperoleh dengan perhitungan seperti Persamaan (1).

Indirect labour cost $=$ indirect labour cost per minute $x$ supervising

b. Kelompok waktu operasi (operating time group)

Digunakan sebagai pemicu biaya pada suatu grup operasi pekerjaan yang merupakan operasi dari suatu peralatan tunggal atau beberapa peralatan.

c. Kelompok throughtput (throughtput group)

Digunakan sebagai pemicu biaya bila biaya utama dari suatu aktivitas ditentukan oleh unit throughtput. 
d. Kelompok kepemilikan (occupancy group)

Merupakan pemicu biaya yang tepat untuk mendistribusikan biaya tetap (fixed cost), berdasarkan lokasi aktivitas atau aset. Sebagai contoh, depresiasi bangunan, pajak bangunan, pemeliharaan eksterior atau pelayanan keamanan didistribusikan berdasarkan luas area per aktivitas. Kelompok pemicu ini jarang sekali digunakan sebagai dasar untuk penentuan biaya yang terjadi (how much cost), tetapi sering dipakai untuk menentukan biaya yang harus didistribusikan.

e. Permintaan (Demand)

Dipakai sebagai pemicu bila distribusi biaya pada aktivitas atau pada tujuan biaya didasarkan pada permintaan. Contohnya adalah perawatan, biaya perawatan akan didistribusikan pada aktivitas atau tujuan biaya yang memerlukan pelayanan perawatan saja.

f. Surrogate cost driver

Merupakan data atau ukuran yang sudah tersedia di lapangan dan praktis untuk digunakan dalam mendistribusikan suatu biaya ke aktivitas lain atau departemen lain, apabila pemicu biaya yang secara teoritis benar (ideal) sulit diukur datanya. Ada beberapa aktivitas yang pemicu biayanya sulit ditentukan dengan tepat. Contohnya adalah biaya material dan biaya konversi. Kedua pemicu biaya ini sering dipakai pada perusahaan kecil dan menengah.

Pemahaman yang tidak tepat atas pemicu biaya akan mengakibatkan ketidaktepatan pada pengklasifikasian biaya sehingga menimbulkan dampak bagi manajemen dalam mengambil keputusan. Apabila perusahaan memiliki beberapa jenis produk maka biaya overhead yang terjadi ditimbulkan secara bersamaan oleh seluruh produk. Hal ini menyebabkan jumlah overhead yang ditimbulkan oleh masing-masing jenis produk harus diidentifikasi melalui cost driver.

Setelah mengidentifikasi cost driver, maka tarif per unit cost driver dapat diketahui dengan menggunakan Persamaan (2).

(2)

Tarif per unit cost driver $=\frac{\text { Jumlah aktivitas }}{\text { Cost driver }}$

2. Identifikasi kelompok biaya (cost pool) Kelompok biaya didefiniskan sebagai sekelompok biaya yang mempunyai karakteristik yang sama yang berkaitan dengan tolok ukur aktivitas yang sama, yang dimaksudkan untuk pembebanan biaya ke produk. Kelompok biaya digunakan untuk mempermudah manajemen dalam membebankan biayabiaya yang timbul, berisi aktivitas yang biayanya memiliki korelasi positif antara cost driver dengan biaya aktivitas. Tiaptiap kelompok biaya menampung biayabiaya dari transaksi-transaksi yang homogen. Semakin tinggi tingkat kesamaan aktivitas yang dilaksanakan dalam perusahaan, semakin sedikit kelompok biaya yang dibutuhkan. Sistem biaya yang menggunakan beberapa kelompok biaya akan lebih menjelaskan hubungan sebab-akibat antara biaya yang timbul dengan produk yang dihasilkan. Kelompok biaya berguna untuk menentukan cost pool rate yang merupakan tarif biaya overhead pabrik per unit cost driver yang dihitung untuk setiap kelompok aktivitas. Tarif kelompok dihitung dengan rumus total biaya overhead untuk kelompok aktivitas tertentu dibagi dasar pengukuran aktivitas kelompok tersebut.

Prosedur Tahap II: Pembebanan activity cost ke produk/jasa. Prosedur tahap kedua ini ditujukan untuk menghitung secara akurat biaya produk atau jasa. Struktur pembebanan biaya ke aktivitas ditunjukkan pada Gambar 3. Pada tahap kedua ini, setiap kelompok biaya ditelusuri ke produk. Hal ini dilakukan dengan menggunakan tarif kelompok yang dihitung pada tahap pertama dan dikalikan dengan jumlah sumber daya yang 
dikonsumsi oleh setiap produk. Tolok ukur ini merupakan kuantitas pemicu biaya yang digunakan oleh setiap produk. Penentuan kelompok biaya selanjutnya digunakan untuk menghitung besarnya biaya overhead pabrik (BOP) yang dibebankan.

$$
\begin{gathered}
\text { BOP yang dibebankan }=\text { (tarif cost } \\
\text { driverlunit) } \mathrm{x} \text { (cost } \\
\text { driver) (3) }
\end{gathered}
$$

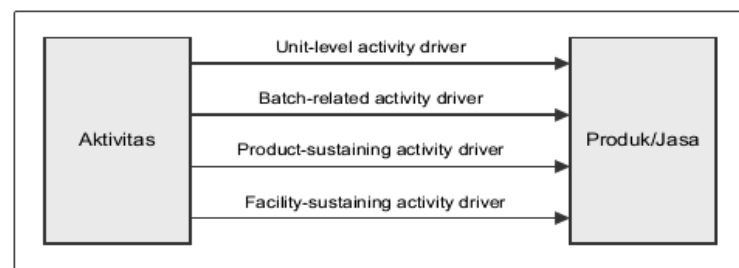

Gambar 2.3. Prosedur tahap II

(Sumber: Tunggal, 1992)

Perhitungan tarif biaya untuk setiap unit produk dapat diketahui dengan menggunakan Persamaan (4). (4)

$$
\text { Tarif per produk }=\text { biaya } \text { produk }+ \text { laba }
$$

\section{HASIL DAN PEMBAHASAN}

Berdasarkan waktu pengerjaan, manajemen UD. KN membagi jenis produk Kayu gergajian (KG) menjadi tiga, yaitu KG kecil, KG besar dan KG campur. KG kecil terdiri dari sortimen papan lis papan sempit broti kecil dan KG pendek. KG besar terdiri dari sortimen papan lebar, papan tebal, balok dan broti besar. KG campur terdiri dari campuran sortimen yaitu KG kecil dan KG besar, biasanya KG campur ini digunakan untuk bahan membuat rumah (balungan/kerangka rumah). Data produksi tiap jenis KG di UD. $\mathrm{KN}$ dapat dilihat pada Tabel 1.

Tabel 1. Data produksi

\begin{tabular}{|l|c|c|c|c|}
\hline Jenis KG & $\begin{array}{c}\text { Produksi } \\
\text { per tahun } \\
(\mathrm{m} 3)\end{array}$ & $\begin{array}{c}\text { Kapasitas } \\
\text { Produksi } \\
(\mathrm{m} 3 / \text { hari })\end{array}$ & $\begin{array}{c}\text { Jam } \\
\text { operasional } \\
\text { (jam/m3) }\end{array}$ & Harga per $\mathrm{m}^{3}$ \\
\hline KG kecil & 700,4174 & 8,5 & 0,94 & Rp195.000,00 \\
\hline KG besar & 870,2155 & 11,0 & 0,72 & Rp195.000,00 \\
\hline KG campur & 1188,5871 & 10,0 & 0,80 & Rp195.000,00 \\
\hline
\end{tabular}

Perhitungan biaya tenaga kerja langsung dilakukan dengan menjumlahkan semua biaya gaji masing-masing pekerja bagian produksi dikalikan dengan hari kerja untuk menghasilkan produk yang diinginkan. Data gaji tenaga kerja langsung per hari pada setiap bagian produksi dapat dilihat pada

\begin{tabular}{|c|c|c|c|c|}
\hline \multicolumn{2}{|c|}{ Stasiun Kerja } & Jumlah & Gaji/hr & Gaji/th \\
\hline \multirow{3}{*}{ Bandsaw 1} & Kepala Bandsaw 1 & 1 & Rp. 70.000 & Rp. 21.840 .000 \\
\hline & Anggota & 3 & Rp . 60.000 & Rp. 56.160 .000 \\
\hline & Pembantu & 2 & Rp. 50.000 & Rp. 31.200 .000 \\
\hline \multirow{3}{*}{ Bandsaw 2} & Kepala Bandsaw 2 & 1 & Rp. 65.000 & Rp. 20.280 .000 \\
\hline & Anggota & 2 & Rp. 60.000 & Rp. 37.440 .000 \\
\hline & Pembantu & 1 & Rp. 50.000 & Rp. 15.600 .000 \\
\hline \multicolumn{4}{|r|}{ Total } & Rp. 182.520 .000 \\
\hline
\end{tabular}
Tabel 2.

Tabel 2. Data gaji tenaga kerja langsung UD.

$\mathrm{KN}$

Biaya tenaga kerja langsung per $\mathrm{m}^{3} \mathrm{KG}$

Kecil =

Jumlah gaji pertahun $x$ waktu produksi KG kecil $/ m 3$ jam operasional produksi pertahun

$$
=\frac{R p \cdot 182.520 .000 \times 0,94 \mathrm{jam}}{2242,97 \mathrm{jam}}=R p .76 .587,53
$$

Biaya tenaga kerja langsung per $\mathrm{m}^{3} \mathrm{KG}$

Besar =

Jumlah gaji pertahun $x$ waktu produksi KG besar $/ m 3$ jam operasional produksi pertahun

$=\frac{R p \cdot 182.520 .000 \times 0,73 \mathrm{jam}}{2242,97 \mathrm{jam}}=R p .59 .181,27$

Biaya tenaga kerja langsung per $\mathrm{m}^{3} \mathrm{KG}$ Campur $=$

Jumlah gaji pertahun $x$ waktu produksi KG Campur $/ m 3$ jam operasional produksi pertahun

$=\frac{R p .182 .520 .000 \times 0,8 \mathrm{jam}}{2242,97 \mathrm{jam}}=R p .65 .099,40$

\section{Prosedur Tahap Pertama}

Hasil identifikasi dan pengelompokan aktivitas yang ada di UD. KN sebagai berikut:

1. Aktivitas pemeliharaan inventaris
a. Biaya depresiasi fasilitas,
b. Biaya pemeliharaan mesin/maintenance

2. Aktivitas pemeliharaan karyawan
a. Biaya THR
b. Perlengkapan karyawan .

3. Aktivitas pelayanan bagi pelanggan

a. Biaya bongkar log

b. Biaya bongkar muat produk

c. Biaya tenaga kerja tidak langsung

d. Biaya administrasi dan biaya ATK

e. Biaya Bahan Bakar 
Hasil pembebanan biaya sumber daya ke aktivitas ditunjukkan pada Tabel 3.

Tabel 3. Pembebanan Biaya Sumber Daya ke Aktivitas

\begin{tabular}{|l|l|}
\hline Biaya Sumber Daya & Pengelompokan \\
\hline Biaya administrasi & Berhubungan dengan batch \\
\hline Biaya bongkar log & Berhubungan dengan batch \\
\hline Biaya bongkar muat produk & Berhubungan dengan batch \\
\hline Biaya bahan bakar & Berhubungan dengan fasilitas \\
\hline Biaya depresiasi fasilitas & Berhubungan dengan fasilitas \\
\hline Aktivitas pemeliharaan mesin & Berhubungan dengan fasilitas \\
\hline Biaya THR dan perlengkapan karyawan & Berhubungan dengan fasilitas \\
\hline Biaya tenaga kerja tidak langsung & Berhubungan dengan fasilitas \\
\hline
\end{tabular}

\section{Prosedur Tahap Kedua}

Penentuan cost driver dan cost pool pada UD. Karya Nugraha ditunjukkan Tabel 4.

Tabel 4. Cost pool dan cost driver

\begin{tabular}{|l|l|}
\hline Cost Pool & Cost driver \\
\hline Berhubungan dengan batch & Jumlah batch/truk \\
\hline Berhubungan dengan Fasilitas & Kapasitas normal \\
\hline
\end{tabular}

Pengalokasian biaya dilakukan dengan mengalokasikan biaya-biaya dalam cost pool ke masing-masing produk berdasarkan cost driver masing-masing cost pool yang telah ditetapkan.

Tabel 5. Alokasi cost driver tiap produk

\begin{tabular}{|l|l|l|l|l|}
\hline \multirow{2}{*}{ Cost driver } & \multirow{2}{*}{ Kapasitas } & \multicolumn{4}{|l|}{ Cost driver tiap produk } \\
\cline { 3 - 5 } & & KG kecil & KG besar & KG campur \\
\hline Jumlah batch & 345 truk & 87 truk & 109 truk & 149 truk \\
\hline Jam operasional & 2334 jam & 659,22 jam & 632,88 jam & 950,87 jam \\
\hline
\end{tabular}

Tabel 6. Cost pool homogen

\begin{tabular}{|l|l|l|l|l|}
\hline $\begin{array}{l}\text { Kategori } \\
\text { Aktivitas }\end{array}$ & Pool & Jenis Biaya & Driver & Cost driver \\
\hline \multirow{2}{*}{$\begin{array}{l}\text { Tingkat } \\
\text { batch }\end{array}$} & Pool 1 & Biaya administrasi & Truk & 345 \\
\cline { 2 - 5 } & Pool 2 & Biaya bongkar log & Truk & 345 \\
\hline \multirow{4}{*}{$\begin{array}{l}\text { Tingkat } \\
\text { fasilitas }\end{array}$} & Biaya bongkar muat produk & Truk & 345 \\
\cline { 2 - 5 } & \multirow{2}{*}{ Pool 4} & Biaya bahan bakar & Jam kerja & 2334,22 \\
\cline { 2 - 5 } & \multirow{2}{*}{ Pool 5} & Aktivitas pemeliasi fasilitas & Jam kerja & 2334,22 \\
\cline { 3 - 6 } & & Biaya THR denaga kerja tidak langsin & Jam kerja & 2334,22 \\
\hline
\end{tabular}

Tabel 7. Alokasi biaya overhead

\begin{tabular}{|c|l|r|}
\hline No & Aktivitas & \multicolumn{1}{|c|}{ Biaya (Rp) } \\
\hline 1. & Biaya administrasi & 3.914 .177 \\
\hline 2. & Biaya bongkar log & 55.200 .000 \\
\hline 3. & Biaya bongkar muat produk & 27.600 .000 \\
\hline 4. & Biaya bahan bakar & 43.680 .000 \\
\hline 5. & Biaya depresiasi fasilitas & 14.900 .000 \\
\hline 6. & Aktivitas pemeliharaan mesin & 13.380 .000 \\
\hline 7. & Biaya THR dan perlengkapan karyawan & 9.870 .000 \\
\hline 8. & Biaya tenaga kerja tidak langsung & 124.560 .000 \\
\hline
\end{tabular}

Biaya overhead pabrik memiliki pemicu biaya yang berbeda-beda sehingga perlu untuk dikelompokkan berdasarkan pemicu biaya masing-masing. Kemudian biaya tersebut dibebankan ke dalam masingmasing aktivitas dari tahapan proses produksi berdasarkan pemicu biayanya.

Pengelompokkan tersebut akan dilakukan sebagai berikut :

Cost pool 1 merupakan kelompok biaya aktivitas yang timbul akibat penggunaan sumber daya tidak langsung berdasarkan pada cost driver jumlah batch yang diproduksi oleh perusahaan. Pengelompokan biaya tersebut dapat dilihat pada Tabel 8 .

Tabel 8. Pengelompokkan overhead pabrik berdasarkan cost driver jumlah batch

\begin{tabular}{|l|l|r|}
\hline No & Aktivitas administrasi & Biaya/tahun (Rp) \\
\hline 1. & Biaya penyusutan peralatanpan kantor & 985.000 \\
\hline 2. & Biaya gaji bagian mandor adm & 9.000 .000 \\
\hline 3. & Biaya listrik umum rotal & 2.929 .177 \\
\hline & \multicolumn{2}{r}{ Tor } \\
\hline
\end{tabular}

Cost pool 2 merupakan kelompok biaya aktivitas yang timbul akibat penggunaan sumber daya tidak langsung berdasarkan pada cost driver jumlah truk (batch) yang diproduksi oleh perusahaan. Pengelompokkan biaya tersebut dapat dilihat pada Tabel 9.

Tabel 9. Pengelompokkan biaya overhead pabrik berdasarkan cost driver jumlah truk (batch)

\begin{tabular}{|l|lr|c|}
\hline No & Aktivitas & Biaya (Rp) \\
\hline 1 & Biaya bongkar log & 55.200 .000 \\
\hline 2 & Biaya bongkar muat produk & 27.600 .000 \\
\hline & \multicolumn{2}{|r}{ Total } & 86.714 .177 \\
\hline
\end{tabular}

Cost pool 3 merupakan kelompok biaya aktivitas yang timbul akibat penggunaan sumber daya tidak langsung berdasarkan pada cost driver kapsitas jam kerja dalam mengkonsumsi bahan bakar dalam liter. Kelompok biaya tersebut adalah pemakaian bahan bakar dengan biaya per liter $\mathrm{Rp}$. 7.000,00 digunakan selama setahun. Berdasarkan data produksi perusahaan, total biaya bahan bakar yang dikeluarkan adalah $=$ Rp. $43.680 .000,00$

Cost pool 4 merupakan kelompok biaya aktivitas yang timbul akibat penggunaan sumber daya tidak langsung berdasarkan pada cost driver kapasitas jam kerja mesin. 
Jumlah biaya dalam kelompok tersebut dapat dilihat pada Tabel 10.

Tabel 10. Pengelompokkan overhead pabrik berdasarkan cost driver jam mesin

\begin{tabular}{|c|c|}
\hline Aktivitas & Jumlah per tahun (Rp) \\
\hline Biaya depresiasi fasilitas & 14.900 .000 \\
\hline Aktivitas pemeliharaan mesin & 13.380 .000 \\
\hline Total & 28.280 .000 \\
\hline
\end{tabular}

Cost pool 5 merupakan kelompok biaya aktivitas yang timbul akibat penggunaan sumber daya tidak langsung berdasarkan pada cost driver kapasitas jam kerja pekerja. Berdasarkan data produksi perusahaan, jumlah biaya dalam kelompok tersebut dapat dilihat pada Tabel 11.

Tabel 11. Pengelompokkan overhead pabrik berdasarkan cost driver jam kerja

\begin{tabular}{|c|c|}
\hline Aktivitas & Jumlah per tahun (Rp) \\
\hline Biaya THR dan perlengkapan karyawan & 9.870 .000 \\
\hline Biaya tenaga kerja tidak langsung & 124.560 .000 \\
\hline Total & 134.430 .000 \\
\hline
\end{tabular}

Setelah mengidentifikasi cost driver, kemudian menentukan tarif per unit cost driver, karena setiap aktivitasnya memiliki cost driver dengan cara membagi jumlah biaya dengan cost driver. Tarif per unit cost driver dapat dihitung dengan Persamaan (2). Berikut ini merupakan penentuan tarif per unit cost driver perusahaan dengan menggunakan metode Activity Based Costing.

Tabel 12. Penentuan Tarif/unit cost driver

\begin{tabular}{|c|c|c|c|}
\hline Cost pool & Biaya overhead $(\mathrm{Rp})$ & Kapasitas & Tarif/unit cost driver $(\mathrm{Rp})$ \\
\hline 1 & 12.914 .177 & 345 truk & $37.432,40 / \mathrm{truk}$ \\
\hline 2 & 86.714 .177 & $345 \mathrm{truk}$ & $251.345,40 / \mathrm{truk}$ \\
\hline 3 & 43.680 .000 & $2334 \mathrm{jam}$ & $18.714,65 / \mathrm{jam}$ \\
\hline 4 & 28.280 .000 & $2334 \mathrm{jam}$ & $12.116,54 / \mathrm{jam}$ \\
\hline 5 & 134.430 .000 & $2334 \mathrm{jam}$ & $57.596,40 / \mathrm{jam}$ \\
\hline
\end{tabular}

Perhitungan biaya overhead pabrik (BOP) yang dibebankan dapat diketahui menggunakan rumus pada Persamaan (3). Perhitungan tarif biaya pelayanan per unit produk yang diteliti dapat dihitung menggunakan Persamaan (4).

Tabel 13. Pembebanan BOP pada kayu gergajian kecil

\begin{tabular}{|c|c|c|c|c|}
\hline No & Biaya overhead & Tarif cost driver (Rp) & Driver & Total Biaya (Rp) \\
\hline 1 & Pool 1 & $37.432,40$ & 87 & $3.256 .618,55$ \\
\hline 2 & Pool 2 & $251.345,40$ & 87 & $21.867 .053,33$ \\
\hline 3 & Pool 3 & $18.714,65$ & 659,22 & $12.337 .073,52$ \\
\hline 4 & Pool 4 & $12.116,54$ & 659,22 & $7.987 .464,27$ \\
\hline 5 & Pool 5 & $57.596,40$ & 659,22 & $37.968 .699,49$ \\
\hline \multicolumn{4}{|c|}{ Total Biaya } & $83.416 .909,15$ \\
\hline \multicolumn{4}{|c|}{ Jumlah Produk $\left(\mathrm{m}^{3}\right)$} & 700,4174 \\
\hline \multicolumn{4}{|c|}{ BOP KG kecil/ $\mathrm{m}^{3}$} & $119.095,99$ \\
\hline
\end{tabular}

Tabel 14. Pembebanan BOP pada kayu gergajian Besar

\begin{tabular}{|c|c|c|c|c|}
\hline No & Biaya overhead & Tarif cost driver (Rp) & Driver & Total Biaya (Rp) \\
\hline 1 & Pool 1 & $37.432,40$ & 109 & $4.080 .131,28$ \\
\hline 2 & Pool 2 & $251.345,40$ & 109 & $27.396 .653,02$ \\
\hline 3 & Pool 3 & $18.714,65$ & 632,88 & $11.844 .129,56$ \\
\hline 4 & Pool 4 & $12.116,54$ & 632,88 & $7.668 .314,65$ \\
\hline 5 & Pool 5 & $57.596,40$ & 632,88 & $36.451 .610,28$ \\
\hline \multicolumn{4}{|c|}{ Total Biaya } & $87.440 .838,81$ \\
\hline \multicolumn{4}{|c|}{ Jumlah Produk $\left(\mathrm{m}^{3}\right)$} & 870,2155 \\
\hline \multicolumn{4}{|c|}{ BOP KG besar $/ \mathrm{m}^{3}$} & $100.481,82$ \\
\hline
\end{tabular}

Tabel 15. Pembebanan BOP pada kayu gergajian Campur

\begin{tabular}{|c|c|c|c|c|}
\hline No & Biaya overhead & Tarif cost driver (Rp) & Driver & Total Biaya (Rp) \\
\hline 1 & Pool 1 & $37.432,40$ & 149 & $5.577 .427,17$ \\
\hline 2 & Pool 2 & $251.345,40$ & 149 & $37.450 .470,65$ \\
\hline 3 & Pool 3 & $18.714,65$ & 950,87 & $17.795 .202,06$ \\
\hline 4 & Pool 4 & $12.116,54$ & 950,87 & $11.521 .252,61$ \\
\hline 5 & Pool 5 & $57.596,40$ & 950,87 & $54.766 .689,85$ \\
\hline \multicolumn{4}{|c|}{ Total Biaya } & $127,111.042,30$ \\
\hline \multicolumn{4}{|c|}{ Jumlah Produk $\left(\mathrm{m}^{3}\right)$} & 1188,5870 \\
\hline \multicolumn{4}{|c|}{ BOP KG campur/ $\mathrm{m}^{3}$} & $106.942,98$ \\
\hline
\end{tabular}

\section{Tabel 16 Penentuan HPP}

\begin{tabular}{|l|l|l|l|}
\hline Biaya & KG Kecil & KG Besar & KG Campur \\
\hline Biaya Tenaga Kerja Langsung $/ \mathrm{m}^{3}$ & $76.587,53$ & $59.181,27$ & $65.099,40$ \\
\hline Biaya overhead/m $\mathrm{m}^{3}$ & $119.095,60$ & $100.481,82$ & $106.942,98$ \\
\hline Harga Pokok Pelayanan $/ \mathrm{m}^{3}$ & $195.682,13$ & $159.663,09$ & $172.942,38$ \\
\hline Biaya Pelayanan & $215.000,00$ & $175.000,00$ & $189.000,00$ \\
\hline
\end{tabular}

Berdasarkan hasil perhitungan yang sudah diperoleh, dapat dibandingkan biaya pelayanan untuk masing-masing jenis produk sebagai berikut:

Tabel 17. Perbandingan Biaya Pelayanan ABC dan UD. KN

\begin{tabular}{|l|c|c|c|c|}
\hline \multicolumn{1}{|c|}{ Jenis KG } & Sistem ABC & Harga UD.KN & Selisih & Keterangan \\
\hline KG kecil & Rp $215.000,00$ & Rp $195.000,00$ & Rp 20.000,00 & Undercosting \\
\hline KG besar & Rp $175.000,00$ & Rp $195.000,00$ & Rp 20.000,00 & Overcosting \\
\hline KG campur & Rp $189.000,00$ & Rp $195.000,00$ & Rp $6.000,00$ & Overcosting \\
\hline
\end{tabular}

Hasil perhitungan biaya pelayanan dengan metode $\mathrm{ABC}$ pada produk $\mathrm{KG}$ kecil lebih besar dari biaya pelayanan saat ini di UD. KN (undercosting). Sedangkan perhitungan pada produk $\mathrm{KG}$ besar dan KG campur menghasilkan biaya pelayanan yang lebih besar (overcosting) dibandingkan dengan harga pokok produksi menggunakan sistem ABC. Perbedaan yang terjadi antara harga biaya pelayanan yang digunakan UD. KN dan sistem $\mathrm{ABC}$ disebabkan karena adanya pembedaan pembebanan biaya overhead 
pada masing-masing produk. Pada sistem perusahaan UD. KN biaya overhead produk hanya dibebankan pada satu cost driver saja, sedangkan pada sistem ABC, biaya overhead pada masing-masing produk dibebankan pada banyak cost driver sesuai aktivitas-aktivitas yang dilakukan dalam proses produksi tiap jenis produk. Sehingga penentuan biaya pelayanan dalam sistem ABC mampu mengalokasikan biaya aktivitas ke setiap produk dengan lebih akurat berdasarkan konsumsi masing-masing aktivitas.

\section{KESIMPULAN}

Harga pokok jasa perusahaan UD. KN dengan metode $\mathrm{ABC}$ adalah: untuk produk KG kecil sebesar Rp. $215.000,00 / \mathrm{m}^{3}$, produk KG besar Rp. $188.000,00 / \mathrm{m}^{3}$ dan produk KG campur Rp. 174.000,00/ $\mathrm{m}^{3}$.

\section{DAFTAR PUSTAKA}

Garrison, R.H., Noreen, E.W., 2000, Akuntansi Manajerial, Buku 1, Salemba Empat, Jakarta.

Gaspersz, V., 2006, Continuous Cost Reduction Through Lean-Sigma Approach, Gramedia Pustaka Utama, Jakarta.

Mulyadi, 2007, Activity Based Costing System, UPP STIM YKPN, Yogyakarta.

Mulyadi, 2005, Akuntansi Biaya, STIE YKPN, Yogyakarta.

Tunggal, A.W., 1992, Activity Based Costing Suatu Pengantar, Rineka Cipta, Jakarta. 